DOI https://doi.org/10.30525/978-9934-26-007-0-23

\title{
FORENSIC PREVENTION: THE CONCEPT OF IMPLEMENTATION IN UKRAINE
}

\author{
Filipenko N. Ye., Spitsyna H. O.
}

\section{INTRODUCTION}

In modern realities, when the development of technology has caused a rapid rise in all aspects of public life, it is extremely difficult to imagine solving controversial problems of administrative, commercial, civil, criminal and arbitration proceedings without the development and deepening of forensic science activity. The use of advanced achievements of the humanities, law, natural sciences, technical sciences allow to solve complex issues in the field of technology, science, art, and crafts at a high professional level. Current level of normative, legal, scientific, methodological, administrative-organizational support of forensic activity allows us to assert that it increasingly plays a key role in the protection of justice and impartial and qualified resolution of cases.

At the same time, to understand the essence of such a complex phenomenon as forensic prevention, current state clarification, analysis and forecasting of trends and prospects for its development, it is important to study the history of the emergence and development of the scientific category. Effectiveness of the crime investigation process largely depends on the results of forensic researches. In turn, the quality of forensic researches depends on organization of research institutions to create effective analysis methods of various corpora delicti ${ }^{1}$. The current period of development of legal science in Ukraine is associated with the need to solve a number of problems, among which a significant place is occupied by issues of study and creative analysis of scientific developments, ways to use scientific and technical achievements, identifying promising areas of research and more. Consideration of these issues is impossible without a deep, unbiased study of the history of science in general and its separate fields. This is especially true of applied sciences, the results of scientific researches that can be relatively quickly implemented in specific practical activities. The general theoretical and applied sciences include criminalistics and forensic science that are designed to provide their recommendations for the practice of combating crime.

Scientific achievements not only enrich the theoretical achievements of science, but also determine the further path of development of practice, provide scientific principles for optimizing such activities. In law enforcement and law enforcement

\footnotetext{
${ }^{1}$ Бахін В.П., Лисиченко В.К. Проблеми науково-методичного забезпечення слідчої діяльності. Теоретичні та практичні проблеми використання можливостей криміналістики і судової експертизи у розкритті й розслідуванні злочинів. Київ : НАВС. 1996. С. 5-11.
} 
fields, theoretical understanding of ways to improve practice is particularly important because the possibilities for experimentation, as a form of theoretical forecasting verification are very limited ${ }^{2}$. This is especially true of preventive activity that is a general term and covers all types of impact on crime.

By general prevention we mean one of the areas of social management which is to prevent and stop specific crimes and crime itself as a social phenomenon. In other words, crime as an integral part of development and functioning of society, develops, professes and implements its own interests, generates the latest properties that come into conflict with the values protected by law. There can be no compromises in this confrontation, because in the event of a loss, the state and society self-destruct. Professional legal sources have repeatedly expressed the opinion that the fight against crime is a special kind of interaction between two opposing parties of social life ${ }^{3}$.

As experts rightly noted in this regard, preventive activities cover three areas:

1) general organization of such activities: set of organizational (accounting, registration), management (forecasting, planning, coordination, definition of strategy and tactics), preventive (implementation of programs and plans, implementation of preventive measures), control (study of practice, crime trends) actions of various bodies and institutions that interact with each other to achieve common results;

2) law enforcement activity consisting in the implementation by specially authorized state bodies of measures provided by law to prevent the development of criminal intent in the previous stages of the crime, identify signs of crimes, identify those who committed them, bring these people to justice, restore violated rights, freedoms and the legitimate interests of the people and the compensation of damages from criminal acts;

3) crime prevention, which means the implementation of economic, political, ideological, educational, legal and other measures to combat crime - is the activity to identify and eliminate the causes of crime, certain types and groups of crimes, specific crimes to prevent the completion of crimes at different stages development of criminal behavior ${ }^{4}$.

Despite a declining trend in crime in recent years, the level of latent crime remains quite high, new types of crime are constantly appearing, primarily related to the development of the Internet, the improvement of IT technologies, the globalization of crime, and so on.

\footnotetext{
2 Тевлін Р. Про поняття «правоохоронні органи» у вузькому та широкому розумінні. Право. 985. Вип. № 7. С. 52-54.

${ }^{3}$ Криминология. Учебник для юридических вузов / Под общей редакцией доктора юридических наук, профессора А.И. Долговой. Москва : Издательская группа НОРМА ИНФРА, 1999. С. 209.

4 Алексеев А.И., Герасимов С.И., Сухарев А.Я. Криминологическая профилактика: теория, опыт, проблемы. Монография. Москва. Издательство НОРМА, 2001. С. 1-23.

Долгова А.И. Криминология. Москва. Издательская группа НОРМА-ИНФРА, 1999. С. 324-338.
} 
Another major factor influencing the course and effectiveness of preventive activities is the problem of timely recording and initiation of criminal cases or misdemeanors based on available information. The vagueness and complexity of disguised crimes, impossibility of identifying the perpetrators, the shortcomings of the regulatory framework of law enforcement agencies, the imperfection of the interaction of forensic officers with investigators at the stage of criminal proceedings, greatly affect the preventive activities, its efficiency and effectiveness in modern conditions.

\section{Analysis of publications where this problem solution is initiated}

Problems of crime prevention were subjected to scientific analysis in the theory of criminalistics, criminology and other related field of law. This was devoted to the work of Soviet-era scientists, contemporary domestic scientists and specialists from foreign schools. Among them: T.V. Averianova, I.A. Aliiev, F.H. Aminiev, M.I. Bazhanov, V.S. Batyrharieieva, R.S. Belkin, Yu.I. Bytko, A.F. Volobuiev, V.V. Holina, D.P. Hurina, F.E. Davudov, I.M. Danshyn, O.M. Dzhuzha, V.A. Zhuravel, A.V. Ishchenko, V.Iu. Kvashys, O.M. Kliuiev, V.P. Kolmakov, V.O. Konovalova, V.K. Lysychenko, V.H. Lukashevych, V P. Loshmanov, V.V. Lukianenko, H.A. Matusovskyi, H.M. Minkovskyi, O.H. Mikhailiants, P.P. Mykhailenko, O.M. Moisieiev, I.V. Pyrih, E. B. Simakova-Yefremian, O.P. Sniherov, N.Ie. Filipenko, I.Ia. Fridman, V.Iu. Shepitko, O.V. Shesler, V.M. Sherstiuk, M.H. Shcherbakovskyi, O.P. Uhrovetskyi, M.P. Iablokov, V.S. Iadykin and others ${ }^{5}$. Despite the significant contribution to the development of the doctrine of the basics of expert prevention of forensic institutions and the accumulated knowledge of expert warning in certain types of expert research, the scientific works of these scientists have not exhausted this problem, but, on the contrary, raised a number of new issues. After all, in recent years, a number of new views on the organization of forensic science institutions (hereinafter referred

\footnotetext{
${ }^{5}$ Алиев И.А. Проблемы экспертной профилактики. Баку: Азернешр, 1991. 312 с.

Алиев И.А., Аверьянова Т.В. Концептуальные основы общей теории судебной экспертизы. Баку, 1992.

Колмаков В.П. Некоторые вопросы криминалистической профилактики преступлений. Советское государство и право, 1961. № 12. С. 106-109.

Фридман И.Я. Судебная экспертиза и вопросы предупреждения пре ступлений : автореф. дис. ... д-ра юрид. наук, 1974. 40 с.

Зудин В.Ф. Предупреждение преступлений в практике судебной экспертизы. Советская юстиция, 1962. № 21. С. 19-24.

Основи судової експертизи: навчальний посібник для фахівців, які мають намір отримати або підтвердити кваліфікацію судового експерта / авт.-уклад.: Л.М. Головченко, А.І. Лозовий, Е.Б. СімаковаЄфремян та ін. Харків : Право, 2016. 928 с.

Пиріг І.В. Теоретичні основи експертного забезпечення досудового розслідування : дис. ... д-ра юрид. наук : 12.00.09. Харків, 2015.

Філіпенко Н.С., Угровецький О.П., Шарапова О.В. Теоретичні основи експертної профілактики: поняття та завдання / Теорія та практика судової експертизи i криміналістики. Том 20. № 2(2019), 2019. С. 151-163. та ін.
} 
to as FSI), their priorities, reform processes and features of the independent functioning of experts who are not employees of the FSI. There have also been significant, coordinating changes in the legal regulation of forensic science institutions and individual independent experts. Instead, expert institutions have accumulated extensive practical experience of preventive activities, which requires further theoretical development, generalization and rethinking, in order to develop the most effective methods of combating crime. One of such issues is the consideration of the essence, content, object and subject of the private theory of expert prevention and the implementation of its developments in the practice of forensic institutions and independent experts.

\section{Main content presentation}

The nature of the knowledge of each science is determined solely by its subject matter as part of the objective reality that a particular science studies. The use of knowledge of other sciences does not change their topic, this knowledge is only adapted to solve the tasks assigned to this science. While developing theoretical foundations and corresponding recommendations addressed to expert practice, the theory of forensic science uses the so-called "specific expertise" and transforms them into legal knowledge, which optimizes the implementation of special knowledge in legal proceedings ${ }^{6}$.

Criminology and forensic science not directly including sectoral forensic knowledge and practical types of forensic science, serve expert practice indirectly, by developing general theoretical principles and origins of modern forensic methodology including standard methods based on basic tools and modern computer technology, should play the role of methodological guidelines in the construction of industry expert disciplines and their inherent expert methods, techniques and technologies.

Ranking and purpose of forensic examination, as a theoretical category is as follows: first, , having a dual nature, it should take over the scientific service of all aspects of practical forensic activity, in the context of developing practical procedural recommendations for forensic experts in all types of proceedings (criminal, administrative, civil, etc.); secondly, in close cooperation with procedural science, forensic examination should actively improve the legal framework of state policy in the field of forensic justice; thirdly, it cannot be outside the development of scientific principles of organizational and managerial aspect of experts, which would ensure the most effective functioning of state forensic institutions as an important component of the judiciary and the judiciary;

\footnotetext{
${ }^{6}$ Сегай М.Я. Судова експертологія: шляхи становлення та розвитку / Теорія та практика судової експертизи і криміналістики: 3б. наук. практ. матеріалів / За загал. ред. М.Л. Цимбал, Е.Б. СімаковаЄфремян, В.М. Шерстюк та ін. Харків : Право, 2001. С. 10.
} 
fourth, forensic examination, constantly evolving and changing, prepares a large array of modern specialists, both scientists and professionals.

On the basis of criminalistics theories of identification and recognition scientific foundations that were laid by S.M. Potapov ${ }^{7}$; theories, methods and techniques of forensic identification, diagnosis and situation were formed that differ significantly from investigative methods of identification, recognition, situational analysis of crime. The tactics of appointing an examination in terms of content do not coincide with the concept of tactics of conducting an examination. Quite a different meaning includes the use of specific expertise by investigators in the criminalistics methods of investigation of certain categories of crimes and methods of using specific expertise by an expert who professionally "serves" specific types of crimes (forensic doctor, auto expert, motor mechanic, and others). The investigator professional knowledge and the expert specific expertise on the criminalistics characteristic of the crime and the methods of including this knowledge by everyone in their professional activities have both common and distinctive features.

Currently we see a tendency to gradually update forensic science as a theoretical category, its transformation into a more capacious than before, a kind of theoretical knowledge that serves not only the law but also the needs of management. It is about the active extension of forensic activity not only in the field of civil, commercial or administrative proceedings but also in other areas of public activity that require professional expertise to make important decisions in the field of law, management, economics ${ }^{8}$. Such a field of expert activity should have clearly defined regulatory, methodological and organizational principles ${ }^{9}$.

An important condition for improving the effectiveness of preventive activities is to intensify the use of scientific and technological progress in the detection and investigation of crimes. Forensic science as a synthetic branch of knowledge very productively contributes to introduction into investigative practice of modern advances in science and technology. However, the problems of interconnection and interaction of forensic science and investigative practice are among the most complex in forensic theory and practice. The solution of these problems largely depends on an adequate understanding of the dynamic processes within science itself associated with its development, changing priorities, updating the knowledge itself.

\footnotetext{
${ }^{7}$ Потапов С.М. Введение в криминалистику. Москва : Госюриздат, 1946. 285 с.

${ }^{8}$ Сегай М.Я. Судова експертологія: шляхи становлення та розвитку / Теорія та практика судової експертизи і криміналістики: 3б. наук. практ. Матеріалів / За загал. ред. М.Л. Цимбал, Е.Б. СімаковаЄфремян, В.М. Шерстюк та ін. Харків : Право, 2001. С. 11-12.

9 Калдин В.Я. Теоретические основы и практика применения идентификации при расследовании и судебном рассмотрении уголовных дел : автореф. дис. ... д-ра юрид. наук. Москва, 1970. С. 23.
} 
The growing interest in science as a higher form of knowledge of objective reality by philosophers, sociologists, lawyers, social scientists is a characteristic feature of the current stage of development of scientific and technological progress. Among the issues which consideration largely provides an adequate understanding of science, a significant place is occupied by the problem of its topic and object. The issue of the science topic includes a large number of nuances, a wide range of phenomena and circumstances that are constantly changing making it an "eternal" problem for each field of knowledge. Science goes through several stages in its development. The process of science evolution can be divided into several periods: a) genesis of a certain system of knowledge; b) knowledge differentiation; c) knowledge integration ${ }^{10}$. Formation of a scientific discipline is impossible without defining the range of its interests. Further development of science objectively leads to its differentiation, the formation of new branches of knowledge that requires the specification of the subject of so-called "maternal" science and separate from its independent areas, clarification between them the topic of scientific cognition.

Further development involves the integration of sciences. Given that the outlined stages are interdependent, do not have clear time limits, include both differential and integration processes, the relevance of the study of the subject of science with its development does not decrease but increases. Manifestations of these provisions have their own specifics in relation to specific areas of knowledge and especially in relation to young applied sciences including forensic science. The origins of this rather complex problem lie in the natural difference between the object of science and its topic. This is an interesting theoretical collision because many legal sciences study the same events or phenomena that may coincide or be similar in content. It is for the purpose of a clear delineation of sciences in the context of the coincidence of the studied phenomena that the theoretical concepts topic of science and object of science were introduced into scientific circulation. In this regard, M. I. Baiting noted that each science has its own object and topic of study that are closely related but do not match. The object concept is broader, it covers the phenomena of the external world extending to cognition and practical influence of subjects, people $^{11}$ The topic is a part, a side of this or that concrete aspect of object investigated by the given science; this is the range of the most important studying issues. If the object is usually common to a number of sciences, the subject of one science cannot coincide with the topic of another ${ }^{12}$.

\footnotetext{
${ }^{10}$ Козлов В.А. Проблемы предмета и методологии общей теории права. Ленинград, 1989. С. 34-35.

11 Байтин М.И. Сущность права (Современное нормативное правопонимание на грани двух веков). Монография. Саратов : СГАП, 2001. 416 с.

${ }_{12}$ Машков А. Проблеми теорії держави і права. Основи: Курс лекцій. URL : https://pidruchniki.com/ 12461220/pravo/viznachennya_ponyat_obyekt_nauki_predmet_nauki_zagalna_harakteristika_protsesu_ formuvannya.
} 
The object of science is understood as a holistic system with a certain structural organization with different levels of internal and external relationships and interdependencies having not only a certain stability but also its own dynamics of development ${ }^{13}$.

The existence of a common object of research for different sciences is emphasized by the majority of criminologists who are specially engaged in the study of the problem of expert institutions ${ }^{14}$. In our opinion, the long discussions of legal lawyers that continue in our time, about the fields of interests of criminalistics, criminal procedure, forensic science are largely caused by the fact that the object of research is included in the system of a science. It should be noted that the object of science is a certain part (fragment) of objective reality having a qualitative certainty and homogeneity that opposes the subject of activity, cognition ${ }^{15}$. Based on this, the system of science includes not the object of study but knowledge about it in the form of concepts, positions, ideas, views, theories, hypotheses reflecting the real object, its qualities, features, relationships, connections, the laws of its formation, development and functioning.

The object of science cannot remain unchanged. Its evolution highlights new, previously unknown aspects and circumstances. On the other hand, the development of science itself not only expands the range of knowledge about a particular object, but also opens previously unknown aspects, connections, relationships and, as a consequence, may develop so that the capabilities of the existing complex of sciences that study a particular object (the variety of qualities of the object, its multifaceted, objectively cannot be studied by a single science) is not enough to study. Therefore, the most effective and most promising research are cross-sectoral, butt, which include a system, a set of certain knowledge, approaches, methods of different fields of knowledge. Such sciences include forensic science ${ }^{16}$.

In addition, the knowledge about object and topic of science is evolving. It is supplemented by new provisions, clarifications, in some cases, the system of ideas about the object, its elements or characteristics changes significantly. The dynamism of cognition object, development of science objectively leads to a significant increase in knowledge about the field under study. In this regard, the

\footnotetext{
${ }^{13}$ Козлов В.А. Проблемы предмета и методологии общей теории права. Ленинград, 1989. С. 14.

${ }^{14}$ Криміналістика і судова експертиза: міжвідом. наук.-метод. зб., присвяч. 105-річчю заснування судової експертизи в Україні / Київський НДІ судових експертиз; редкол.: О.Г. Рувін та ін. Київ : Видавництво ЛіраК, 2018. Вип. 63, ч. 1. 424 с.; Ковальова В.В. Шляхи удосконалення експертно-криміналістичної служби МВС України: автореф. дисс. ... канд. юрид. наук. Київ, 2001. 17 с.; Бердичевский Ф.Ю. О предмете и понятийном аппарате криминалистики. Вопросы борьбы с преступностью. Москва,1976. Вып. 24. С. 130-134.

${ }_{15}$ Демичев В.А. Объект и предмет науки. Научные доклады высшей школы: Философские науки. 1983. № 5. С. 129.

${ }^{16}$ Винберг А.И., Малаховская Н.Т. Судебная экспертология (общетеоретические и методологические проблемы судебных экспертиз). Волгоград, 1979. С. 80.
} 
problem of clarifying the subject of science and its object is constantly updated, as the subject of science, just formed in the process of cognition, being an idealized object of science, its theoretical mode ${ }^{17}$. Thus, the problem of the subject of science cannot, in our opinion, belong to the circle of unconditionally solved. Each stage of development makes its own adjustments, opens up new aspects and aspects of this fundamental concept. Adequate understanding of the subject of forensic science, the essence of its subsystems and separates theories is of fundamental importance, because their definition specifies the area of objective reality that is the substantive basis of this area of knowledge, namely the activity which object is expert research.

The private theory of expert prevention did not arise out of nowhere. Its development was preceded by a long and painstaking work on the development of forensic science general theory. The fact that the private theory of forensic prevention studies almost the same object as the general theory of forensic examination, it seems appropriate to pre-analyze the content of general theory topic. In this case, the fact is taken into account that this theory itself is undergoing significant qualitative changes: in the legal regulation of forensic activities; expanding the scope of specific expertise; accumulation and systematization of new factual material, etc.

The process of forming scientific ideas about the subject of forensic science general theory has a long history and is not completed so far. A large number of criminologists (M. Segai, P. Bilenchuk, V. Prokhorov-Lukin, A. Ishchenko, N. Klimenko and others) recognized forensic science as an independent branch of legal science, but differed in their interpretation of its ranking in the system of other fields of knowledge. They believe that its further formation requires a clearer definition of the object and topic of new science, its conceptual foundations, its methodology that should be based on the model of expert cognition and intersectoral teachings for their ontological and epistemological guidelines ${ }^{18}$.

For example, defining the place of forensic expertise in the system of scientific knowledge, O. Eisman noted that it is rather separate part of criminalistics having a specific issue, topic and task. It should be considered a doctrine of forensic science in the criminalistics system $^{19}$. The book by A. Winberg and N. Malakhovskaya: Forensic expertology. General theoretical and methodological problems of forensic examinations and their previous

\footnotetext{
17 Винберг А.И., Малаховская Н.Т. Судебная экспертология (общетеоретические и методологические проблемы судебных экспертиз). Волгоград, 1979. С. 15.

${ }_{18}$ Конспект лекцій 3 дисципліни «Експертологія» для студентів юридичного факультету. ДДУВС. Дніпро, 2016. URL : https://dduvs.in.ua/wp-content/uploads/files/Structure/library/student/lectures/1130/3.1.pdf.

19 Эйсман A.А. Экспертология в системе научного знания. Экспертные задачи и пути их решения в свете НТР: Сб. науч. тр. ВНИИСЭ. Москва : ВНИИСЭ, 1980. С. 65-72.
} 
articles, as well as further clarifications give a complete picture of their concept of a new field of knowledge that they called forensic expertology. These scientists define it as a branch of legal science that studies the laws, methodology, process of formation and development of scientific bases of forensic science, as well as examines their objects allowing to have an idea of the subject of science and its place in the system of scientific knowledge. Forensic expertology should explore the general patterns and methodological problems of the theory of forensic science and not fall to the level of certain types of expertise as a practical specific activity ${ }^{20}$.

According to $\mathrm{O}$. V. Iunatskyi, forensic expertology is a science that studies the patterns of functioning of forensic activity, patterns and methodology of formation and development of examinations, patterns of research of objects of examination, carried out on the basis of specific expertise transformed on the basis of branch sciences into the system of scientific methods, techniques and means of solving expert problems. Within the framework of legal regulation, it should be defined as a synthetic, applied legal science that by its genesis and general research object (criminal activity) belongs to the cycle of criminal law sciences ${ }^{21}$.

As noted in the scientific works devoted to the development of forensic science genesis from the part of criminalistics to an independent scientific category, the general idea of its creation was the main (fundamental) pattern: for all the individual differences of examinations of different genera and species, they all have many common positions expressed in their purpose, theoretical justification, sources, stages of development, functioning, regulation, organization. The conditions that contributed to the solution of the problem of creating a forensic expertology: availability of a large body of empirical material in certain genera (types) of examinations, the creation on this basis of separate theories of these examinations, which reflected their scientific basis and patterns; development of principles, methodological, legal and organizational bases of various kinds of forensic examinations, allocation from this volume of that general that should be inherent in any kind of examination, including that created; the presence of intermediate theoretical developments on certain problems of forensic examination, which are reflected in monographs, articles, educational and methodological literature; the system of methods and techniques of expert research, which is constantly improved and is a reflection of general scientific and technological progress; the presence of a developed system of state forensic institutions in various departments of the country, coordinating their practical and scientific activities. Thus, the purpose of forensic expertology is primarily to

\footnotetext{
${ }^{20}$ Винберг А.И., Малаховская Н.Т. Судебная экспертология. Общетеоретические и методологические проблемы судебных экспертиз: Учеб. пособ. Волгоград : НИиРИО ВШ МВД СССР, 1979. 183 с.

${ }^{21}$ Конспект лекцій 3 дисципліни «Експертологія» для студентів юридичного факультету. ДДУВС. Дніпро, 2016. URL : https://dduvs.in.ua/wp-content/uploads/files/Structure/library/student/lectures/1130/3.1.pdf.
} 
systematize the accumulated so far categories of all kinds (types) of forensic examinations, namely: concept of the forensic examination topic, objects of research, expert tasks, expert specific expertise, concept of expert competence and competence, technology of expert research, etc. ${ }^{22}$

As I.A. Aliiev rightly noted, the general theory of forensic examination should reflect the patterns of origin and development of examinations of different classes, genera, species; to be synthesized and systematized knowledge about forensic examination as a single system about what processes take place in. It should reflect the concept of the subject, general methodology, training on objects, subjects, expert tasks and methods of expert research, theoretical aspects of infrastructure and system-functional analysis of expert activities, as well as prospects for the creation and development of private theories of forensic science. In this case, it should be a legal interdisciplinary theory, substantively related to the criminal process, criminology, with other sciences, including specialized, which form the basis of examinations of different classes, kinds ${ }^{23}$.

The subject of the general theory of forensic examination, according to S.F. Bychkov, is a system of theoretical knowledge that reflects at the metasubject level the general patterns of development of the scientific basis of forensic science and expert activity ${ }^{24}$.

Studying the subject of the general theory of forensic science, T.A. Averyanova emphasizes that it is a system of worldview and praxeological principles of both the theory and its object of expert activity, private theoretical constructions in this field of scientific knowledge, methods of theory development and implementation of expert research, processes and relations, i.e. comprehensive scientific reflection of forensic activities ${ }^{25}$. In our opinion, the disadvantage of this definition is the analysis lack of legal and organizational principles of forensic science.

One of the main factors that significantly affect the study of expert prevention is to take it as a whole as a whole system, to reveal its essence, qualitative specificity, its inherent systemic integration qualities (composition, structure, internal and external organization, relationship of components). The emphasis is on the interaction and interdependence of individual components of the system, the specifics of the functioning of the whole system as a whole. It is necessary to

\footnotetext{
${ }^{22}$ Конспект лекцій 3 дисципліни «Експертологія» для студентів юридичного факультету. ДДУВС. Дніпро, 2016. URL : https://dduvs.in.ua/wp-content/uploads/files/Structure/library/student/lectures/ 1130/3.1.pdf.

${ }^{23}$ Алиев И.А. Проблемы судебно-экспертной профилактики : автореф. дис. ... д-ра юрид. наук : 12.00.09. Киев, 1990. С. 6.

${ }^{24}$ Бычкова С.Ф. Становление и тенденции развития науки о судебной экспертизе. Алма-Ата, 1992. C. 124.

${ }^{25}$ Аверьянова Т.В. Этапы развития судебной экспертизы. Ученые-криминалисты и их роль в совершенствовании научных основ уголовного судопроизводства. материалы межвузов. науч.-прак. конф. (к 85-летию со дня рождения Р.С. Белкина) в 2-х Ч. Ч. 1. М. БЕК, 2007. С. 261.
} 
distinguish between the overall qualities of the system and the individual qualities of consisting elements because they can differ significantly.

The solution of this problem required, in turn, the development of a private theory of forensic prevention. All attempts of theoretical generalizations concerning separate elements of preventive activity, without intention to consider them as components of one system, without application of the scientific analysis of all system as a whole (for example, interconnected processes occurring in this system, their hierarchical communications), failed to build a private theory of forensic prevention.

The creation of theory always marks a qualitatively new stage in the development of scientific knowledge and its positive impact on practice. The private theory of forensic prevention is designed to systematize empirical knowledge and available theoretical generalizations, to describe and explain it, to reveal the patterns of its functioning and development. However, private theory development of forensic prevention required a solution to the issue within which field of knowledge, in the light of which general theory, it can be created and developed.

In developing this question, R. S. Belkin, referring to the works of P.V. Kopnin, wrote that knowledge, to become a theory should reach a certain maturity in its development... The theory should include not only a description of the known set of facts but also their explanation, the laws to which they are subject. The theory includes several provisions expressing regular connections. Moreover, these provisions are united by one common principle reflecting the fundamental laws of the subject (or set of phenomena). If there is no unifying general principle, then no set of scientific propositions that reflect the natural connections will not be a scientific theory ${ }^{26}$. A similar opinion is held by other scientists.

For example, considering the relationship between general theory and private theories of individual genera and types of examinations, T.V. Averyanova and I.A. Aliiev noted that private theories are based on the provisions of general theory and contain as source premises those data that correspond to specifics of certain types or kinds of forensic examinations. In addition to these data of general importance, the content of private theory consists of specific scientific bases of this kind, type of expertise, characteristics of typical research methods and typical or typical methods used to solve again typical for this kind, type of expert tasks. These authors, characterizing private theories, note that they may differ in the level of scientific generalization. In their hierarchy, one can imagine theories of class, kinds, types and even a subtypes of forensic examinations and each subsequent one in this series differs in

\footnotetext{
${ }^{26}$ Криминалистика: Учебник для вузов / Т.В. Аверьянова, Р.С. Белкин, Ю.Г. Корухов, Е Р. Россинская / под ред. Р.С. Белкина. Москва : НОРМА, 2001. С. 285.
} 
greater concretization from the previous one, retaining in its content some provisions common to all these theories ${ }^{27}$.

The basis for the formation of the theory of forensic prevention was a discussion of crime hindering unfolded in the early 60's of last century. Until then, the question of forensic (including expert) prevention in the literature has not been raised. Only some forensic specialists (V.P. Kolmakov, I.Ya. Friedman, V.F. Zudin, I.A. Aliiev) ${ }^{28}$ began to consider the basics of forensic prevention in their research papers. In the research papers of R.S. Belkin devoted to the consideration of private forensic theories, it was argued that in their content they can be more general and less general, reflecting, respectively, a larger or smaller subject area, more or less significant group of phenomena and processes ${ }^{29}$.

One of the first to develop the provisions of the private theory of forensic prevention was a prominent Ukrainian scientist V.P. Kolmakov. However, his work has met with great criticism from some scientists, especially criminologists. One of the ardent opponents of V.P. Kolmakov was I.Ya. Friedman. However, devoting much time to the study of this question and accumulating a certain theoretical array of information, he was forced to agree with V.P. Kolmakov concluding that this particular theory has a right to exist because it is part of the criminalistics topic is part of its general scientific theory but proposed the structure and content of this doctrine ${ }^{30}$. Therefore, other theorists in the field of criminalistics and forensic science considered in their work issues of legal, organizational and methodological nature of expert prevention, paid considerable attention to the problems of monitoring the implementation of recommendations given in the conclusions of experts and sent to law enforcement agencies and other officials whose functional responsibilities include the implementation of such recommendations.

Later, analyzing the theoretical achievements of predecessors and a large array of empirical material, I.A. Aliiev substantiated the need to construct a private theory of expert prevention, defined its principles and functions, content and structure, as well as patterns of its construction and outlined the interaction of its

\footnotetext{
${ }^{27}$ Алиев И.А., Аверьянова Т.В. Концептуальные основы общей теории судебной экспертизы. Баку, 1992. C. 158.

${ }^{28}$ Колмаков В.П. Некоторые вопросы криминалистической профилактики преступлений. Советское государство и право, 1961. № 12. С. 107.

Фридман И.Я. Судебная экспертиза и вопросы предупреждения пре ступлений : автореф. дис...Д-ра юрид. наук, 1974. С. 26.

Зудин В.Ф. Предупреждение преступлений в практике судебной экспертизы. Советская юстищия, 1962. № 21. С. 22.

Алиев И А. Деятельность судебно-экспертных учреждений по предупреждению преступлений. Баку, 1988. С. 56.

${ }^{29}$ Белкин Р.С Криминалистическая энциклопедия. Москва : БЕК, 1997. С. 172.

30 Фридман И.Я. Вопросы правового регулирования профилактической деятельности экспертов и судебно-экспертных учреждений. Криминалистика и судебная экспертиза. Вып. 6. Киев, 1976.
} 
components with other preventive activity ${ }^{31}$. In this regard, R.S. Belkin pointed out that in the context of the general theory of forensic science, the object of which is practical expert activity, private theory has a right to exist because it reflects an independent and also very important direction of expert practice, which can rightly be called crime hindering ${ }^{32}$.

Like most private theories, the theory of expert prevention develops and implements its own system of concepts that are a reflection of reality. After analyzing the opinions of scientists ${ }^{33}$ who have previously considered these issues, we can say that the system of concepts of expert prevention can be divided into three major blocks: basic, intermediate and integral.

Basic concepts of the of forensic prevention theory in most cases coincide with those used in the general theory of forensic science: specific expertise, forensic expert, forensic science, expert conclusion, forensic research.

The second, intermediate, block of the system of concepts forensic prevention theory includes already more specific concepts inherent in this particular theory: tasks of judicial prevention, expert preventive activity, recommendations of the expert on elimination (minimization) of the reasons and conditions which have promoted crime commission, revealing of determinants of crime, etc.

The integral level of concepts corresponds to: set of separate preventive measures used by the expert in the course of his professional activity, structural and functional basis of preventive expert activity, subjects of expert preventive activity, models of preventive expert activity, etc.

Modern domestic scholars, studying the place and role of expert prevention in the system of legal sciences, and in particular, forensic expertise, considered it, mostly in the context of conducting specific forensic examinations.

After their analyzing we see that most scholars understood expert prevention as the establishment on the basis of special knowledge of facts containing data on the circumstances of the event that contributed to the crime (offense) and the transformation of these data through willful acts of legal persons with the ultimate goal of eliminating these circumstances. present and future or minimizing ${ }^{34}$. For example, developing the scientific postulates of forensic expertise, I. V. Pyrih believes that expert prevention is part of its conceptual framework ${ }^{35}$ and stressed

\footnotetext{
31 Алиев И.А. Правовые и организационные проблемы экспертной профилактики. Баку, 1987. С. 21.

${ }^{32}$ Белкин Р.С. Курс криминалистики. В 3 т. Т. 2, Частные криминалистические теории. Москва : Юристь, 1997. С. 161.

${ }^{33}$ Колмаков В.П. Некоторые вопросы криминалистической профилактики преступлений. Советское государство и право, 1961. № 12. С. 106-109.

Аминев Ф. Г. Судебно-экспертная деятельность: современные проблемы и пути их решения : дис. ... докт. юрид. наук. Уфа, 2016. URL : https:/pravo.studio/sudebnaya-ekspertiza/problemyi-teorii-praktiki-sudebnoekspertnoy-105867.html.

${ }^{34}$ Бордюгов Л.Г. Профілактична функція судової екологічної експертизи. URL : http://nauka.kushnir.mk.ua.

${ }^{35}$ Пиріг I.В. Теоретичні основи експертного забезпечення досудового розслідування : дис. ... д-ра юрид. наук : 12.00.09. Харків, 2015. С. 129.
} 
that prevention is the use of these examinations to purposefully influence specific individuals, causes and conditions of crime. The next, logical step in the application of the results and means of expert activity in crime prevention, according to V.Yu. Shepytko, is the use of technical and expert means of crime prevention this present time ${ }^{36}$.

Unfortunately, in most of the analyzed works the problematic issues of preventive activity of a forensic expert are considered mainly in the issues of using the conclusions and results of forensic examinations. We believe that this approach is disproportionate. In this regard, we agree with the views of A.A. Rusetskyi and O.P. Uhrovetskyi who emphasized that the logic of building the latest model of combating crime involves the introduction of the use of expert results at all stages of combating crime, namely to form optimal organizational tactical models of actions of operatives and investigators at the stages of search and detection of signs of criminal activity, preventive measures and during the pre-trial investigation of criminal proceedings. In their opinion, forensic prevention of crimes is a component of counteraction to crimes, which consists in the use of special knowledge aimed at improving the theoretical, legal, organizational and tactical bases of measures, investigative and covert criminal investigation measures. in order to identify and eliminate the circumstances of criminal offenses ${ }^{37}$. We do not completely agree with this definition, as we believe that expert prevention, first of all, is an independent activity of a forensic expert, and, secondly, it cannot serve covert investigative actions. In our opinion, this is a professional activity of a forensic expert aimed at eliminating or minimizing the determinants of crime. Based on the fact that the determinants of crime we mean a set of internal predispositions of a person (his criminal motivation) and external factors that create a certain basis for a person to commit an illegal act. Therefore, the determinants of crime, to a greater extent - legal concepts, because they are based on violations of legal, social or technical norms. It is these shortcomings that the court reveals when considering cases and takes measures to their minimizing or eliminating ${ }^{38}$, we want to offer our own definition of forensic prevention. In our opinion, this is based on laws and regulations of the forensic expert aimed at identifying the

\footnotetext{
${ }^{36}$ Шепитько В.Ю. О новеллах в использовании специальных знаний в уголовном процессе Украины. Теория и практика судебной экспертизы в современных условиях: материалы 4-й междунар. науч.-практ. конф. (г. Москва, 30-31 янв. 2013 г.). Москва : Проспект, 2013. С. 340-342.

37 Русецький А.А., Угровецький О.П. Місце експертної профілактики в системі протидії злочинності. Актуальні питання судової експертизи та криміналістики : зб. матеріалів міжнар. наук.-практ. конф., присвяч. 95-річчю створення Харків. НДІ суд. експертиз ім. Засл. проф. М.С. Бокаріуса (Харків, 10-11 жовт. 2018 р.). Харків : Право, 2018. 250 с. С. 83-86. С. 85.

38 Filipenko N. Ye. Identification of crime determinants while performing forensic expert activities. Proceedings of VI International scientific conference "Scientific achievements during the rapid technological development”. Berlin, tredition GmbH, 2019. P. 161-167.
} 
determinants that contributed to the commission of a particular crime and development of measures to their eliminating (minimizing) using specific expertise. Preventive activity should be carried out: while carrying out forensic examinations regarding specific criminal, administrative or civil cases, by means of generalizing expert and forensic practice; while scientific research on problems of expert prevention; by providing, on the basis of specialized knowledge, scientific and practical assistance to bodies and organizations in identifying circumstances contributing to crime commission etc. ${ }^{3}$

Having understood the essence of forensic prevention, we will consider in more detail its main components. These are the topic, object and principles of forensic prevention.

According to F.G. Aminev, the subject of expert prevention is the patterns of occurrence, detection, collection, research, evaluation and use of forensic information about the circumstances that contribute to the commission of crimes obtained in the course of forensic activities, as well as based on knowledge of these regularities of special means and methods of elimination of the specified circumstances and prevention of the crimes preparing (offenses) ${ }^{40}$.

Having analyzed the results of discussion and statements of scientists on the concept of expert prevention topic and based on our own researches ${ }^{41}$, we give the author's understanding of this theoretical definition. In our opinion, the subject of private theory of forensic prevention are theoretical, normative, legal and organizational laws of preventive activity; regularities of origin and formation of the bases of preventive activity on the basis of the uniform methodology, the unified conceptual device; restructuring and adjustment of theoretical categories taking into account the constant updating, modernization and modification of special expertise; normative, legal and organizational support of preventive expert activity; common language of scientific terminology and unification of preventive standards, etc.

Disclosing the concept of private theory object of expert prevention, we want to note that they can be classified into:

- general objects (material media of information about the criminal event, for example, documents provided for examination by an expert; objects of the surrounding world, referrals for examination for comparison, etc.);

\footnotetext{
39 Філіпенко Н.С., Угровецький О.П., Шарапова О.В. Теоретичні основи експертної профілактики: поняття та завдання. Теорія та практика судової експертизи і криміналістики. Вип. 20. Харків : Право, 2019. С. 3-46.

40 Аминев Ф.Г. Судебно-экспертная деятельность: современные проблемы и пути их решения : дис. ... докт. юрид. наук. Уфа, 2016. URL : https://pravo.studio/sudebnaya-ekspertiza/problemyi-teorii-praktiki-sudebnoekspertnoy-105867.html.

41 Філіпенко Н.Є. Приватна теорія експертної превенції: генеза та сучасний стан. Науковий вісник ДДУВС: науковий журнал. 2019. № 3. С. 137-146.
} 
- characteristic objects (special objects of kinds and types of forensic examinations: for example, accounting documents, audit reports, etc.);

- specific objects (objects examined by an expert during a specific forensic examination).

Based on the content and scope of the studied objects of expert prevention, it can be argued that the problems solved within the framework of this particular theory are divided into two groups: general and special.

The general task of the private theory of expert prevention should be considered the practice of special subjects aimed at combating crime by developing scientific provisions for the use of forensic science in crime prevention. After analyzing the views of scientists ${ }^{42}$, we believe that the special tasks include: establishing the causes and conditions that contribute to the commission of crimes, when conducting expert research; development of methods and means of obtaining reliable knowledge, which provided forensic experts with new opportunities to establish the determinant of crime; development and improvement of measures to increase the effectiveness of general interaction and coordination of activities between employees of forensic institutions and other subjects of preventive activities; introduction of elements of preventive activity in civil, economic, arbitration and administrative proceedings, etc.

The main principles of the expert prevention private theory are: the principle of causality (research on causal relationships, causal actions of the expert to establish criminogenic factors and develop proposals for their elimination); the principle of heredity (is that the private theory of expert prevention implements the laws of criminalistics prevention theory), etc.

Also, the allocation of expert prevention in an independent system is based on the principle of a systematic approach as one of the most promising areas in the development of social research methodology. While such development, a variant of solving a specific system problem should be chosen, namely: isolation of the object under research. This isolation has a dualistic nature: on the one hand, we can identify the levels of the social system and on the other, to determine the sphere of public life, where this system will be the most viable and dynamic.

If we are talking about the system of forensic prevention, in our opinion, the most promising is its distribution (isolation of its elements) at different levels. This will allow the most effective consideration of the forensic prevention system as a single conglomerate of data and will analyze the existing value regulations in the system and the specifics of their implementation ${ }^{43}$.

\footnotetext{
${ }^{42}$ Клименко Н.І. Судова експертологія: Курс лекцій : навчальний посіб. для студ. Київ : Видавничий Дім «Ін Юре», 2007. 528 с.

${ }^{43}$ Алиев И.А. Проблемы экспертной профилактики. Баку : Азернешр, 1991. С. 33.
} 
Such regulations (markers or value invariants) for the expert prevention system are the social, legal and ethical obligation to take preventive measures by employees of forensic science institutions of Ukraine. After all, it is forensic experts who have the opportunity to establish the causes and conditions of crimes, applying specific expertise in practice, have the opportunities to develop and implement a set of special preventive measures. The effect of this special complex invariant of this system extends to the entire forensic science institution.

Thus, the system forming factors of forensic prevention are: implementation of preventive tasks using specific expertise; coordination, information and methodological support of preventive measures; unification of the structure of interconnected subjects of preventive activity; normatively fixed subjects of preventive activity; uniformity of functional support of preventive measures of forensic science institutions of the system of the Ministry of Justice of Ukraine, the Ministry of Internal Affairs.

The possibility and regularity of the use of specific expertise by forensic experts in the implementation of preventive activities is not disputed, because the possibility of forensic science in identifying circumstances that contribute to the commission of crimes, as well as in developing measures to eliminate them are of paramount importance.

\section{CONCLUSIONS}

Based on the results of the analysis of professional sources on this issue and taking into account the authors' own works ${ }^{44}$, we note that:

1. The genesis of forensic science as a scientific and theoretical category convincingly shows that it is in the process of continuous development and a constant factor in its evolution are the processes of differentiation and integration of knowledge in this subject area. In practice, this means the constant emergence of new areas of scientific knowledge which in-depth development often leads to the emergence of new theories within the basic science. Such theories, having received a certain degree of autonomy, deepen (clarify) knowledge within their subject, and at a new theoretical level are embedded in the fabric of basic science, enriching it. In our opinion, such a process occurs with the system of knowledge about forensic prevention private theory .

2. Forensic prevention is a mandatory element of expert technology considered by forensic scientists and proceduralists and leading forensic experts as a

44 Філіпенко Н.С. Приватна теорія експертної превенції: генеза та сучасний стан. Науковий вісник ДДУВС: науковий журнал. 2019. № 3. С. 137-146.

Філіпенко Н.С., Угровецький О.П., Шарапова О.В. Теоретичні основи експертної профілактики: поняття та завдання. Теорія та практика судової експертизи і криміналістики. Вип. 20. Харків : Право, 2019. С. 35-46.

Експертизи в судовій практиці / За заг. ред. В.Г. Гончаренка. Київ : Юрінком Інтер, 2005. 386 с. 
scientific category. This category is based on expert initiative provided by procedural law for the implementation of the expert's right to emphasize in his opinion the facts revealed during the examination, relevant to the case and prevention as an expert's activity to identify circumstances that contributed (could contribute) to the commission study of an offense and about which he was not asked questions.

3 . The development and deepening of the forensic prevention private theory allows us to formulate the basic patterns inherent in the preventive processes of forensic science. These include: organizational and methodological bases of forensic prevention; regularity of obtaining as a result of preventive activity information about the facts or circumstances that contribute to the commission of crimes and the elimination or minimization of their impact on public life; regularity of growth of authority of forensic institution in the conditions of acceleration of scientific and technical progress and perception of results of their activity by the persons who do not possess the corresponding specific expertise; unification of methods and means of preventive activity and support of its invariance in the legal field of expert activity; formation of a specific conceptual apparatus, the language of theory adapting concepts borrowed from other related fields of knowledge to the preventive activities of forensic science institutions.

4. The scope of knowledge systematized by a theory, as well as its place in the general system of science, is determined by its topic. In science, quite often the subject of theory is expressed through a system of studied patterns, generalized and formulated in the form of a definition. In our opinion, the subject of the of forensic prevention private theory are theoretical, normative-legal and organizational laws of preventive activity; regularities of origin and formation of the bases of preventive activity on the basis of the uniform methodology, the unified conceptual device; restructuring and adjustment of theoretical categories taking into account the constant updating, modernization and modification of specific expertise; normative-legal and organizational support of preventive expert activity; common language of scientific terminology and unification of preventive standards, etc.

5. By forensic prevention we mean the activities of a forensic expert based on laws and bylaws, aimed at identifying determinants that contributed to the commission of a particular crime, and the development of measures to eliminate (minimize) them using specific expertise.

6. The topic of forensic prevention private theory are theoretical, normative, legal and organizational laws of preventive activity; regularities of origin and formation of the bases of preventive activity on the basis of the uniform methodology, the unified conceptual device; restructuring and adjustment of theoretical categories taking into account the constant updating, modernization 
and modification of special expertise; normative, legal and organizational support of preventive expert activity; common language of scientific terminology and unification of preventive standards, etc.

7. Disclosing the concept of private theory object of expert prevention, we want to note that they can be classified into: general objects (material media of information about the criminal event, for example, documents provided for examination by an expert; objects of the surrounding world, referrals for examination for comparison, etc.); characteristic objects (special objects of kinds and types of forensic examinations: for example, accounting documents, audit reports, etc.); specific objects(objects examined by an expert during a specific forensic examination).

8. The significance of the forensic prevention private theory lies in the generalization of the direct experience of the organization of such activities that can be expressed in the form of a system of principles. In our opinion, they are formed by: principle of legality and observance of human and civil rights and freedoms; principle of professional independence and professional ethics of experts; principle of confidentiality; principle of leadership of the head of the forensic science institution; principle of qualification and involvement of all staff; principle of continuous improvement of preventive activities; factual principle of decision making, etc.

9. Despite the spread of certain elements of forensic prevention in the practice of forensic science institutions, to date, the development of theoretical foundations, conceptual approaches to its structure and methods of construction are still at an insufficient level of development. Therefore, we consider it necessary to propose a definition of the central concept in the concept of forensic prevention private theory: it is a category with which the set of its characteristics fulfills the requirements of the legal system of the state in the implementation of preventive activities.

\section{SUMMARY}

The article analyzes the conceptual principles, opinions and ideas for understanding the essence of forensic science private theory, namely: forensic prevention concept is considered. The empirical prerequisites for the emergence and development of forensic research have been investigated: accumulation of empirical facts in the theory of forensic science and other sciences, manifestation of integration processes. Theoretical and applied foundations of expert prevention private theory are formulated. Its concept, structure, subject, object and tasks are considered and analyzed. Its place and role in the theory of criminalistics and forensic science are clarified. It is noted that the study of the current state of the theory and practice of private expert 
theory has allowed to establish that it has a common beginning and justification. Private theories, as systems of interconnected components, include: idea, principles, large empirical material that is the theory cornerstone, general and specific tasks, functions and purpose of the theory.

\section{REFERENCES}

1. Аверьянова Т.В., Белкин Р.С., Корухов Ю.Г., Россинская Е.Р. Криминалистика : учебник для вузов / под ред. Р.С. Белкина. Москва : HOPMA, 2001.

2. Аверьянова Т.В. Этапы развития судебной экспертизы. Ученые-криминалисты и их роль в совершенствовании научных основ уголовного судопроизводства. Материалы межвузов. науч.-прак. конф. (к 85-летию со дня рождения Р.С. Белкина) в 2-х ч. Ч. 1. Москва : БЕК, 2007.

3. Алексеев А.И., Герасимов С.И., Сухарев А.Я. Криминологическая профилактика: теория, опыт, проблемы. Монография. Москва : Издательство НОРМА, 2001.

4. Алиев И.А., Аверьянова Т.В. Концептуальные основы общей теории судебной экспертизы. Баку, 1992.

5. Алиев И.А. Деятельность судебно-экспертных учреждений по предупреждению преступлений. Баку, 1988.

6. Алиев И.А. Правовые и организационные проблемы экспертной профилактики. Баку, 1987.

7. Алиев И.А. Проблемы судебно-экспертной профилактики : автореф. дис. ... д-ра юрид. наук: 12. 00. 09. Киев, 1990.

8. Алиев И.А. Проблемы экспертной профилактики. Баку : Азернешр, 1991.

9. Аминев Ф.Г. Судебно-экспертная деятельность: современные проблемы и пути их решения : дис. ... докт. юрид. наук. Уфа, 2016. URL : https://pravo.studio/sudebnaya-ekspertiza/problemyi-teorii-praktiki-sudebnoekspertnoy-105867.html.

10. Байтин М.И. Сущность права (Современное нормативное правопонимание на грани двух веков). Монография. Саратов : СГАП, 2001.

11. Бахін В.П., Лисиченко В.К. Проблеми науково-методичного забезпечення слідчої діяльності. Теоретичні та практичні проблеми використання можливостей криміналістики $і$ судової експертизи у розкритті й розслідуванні злочинів. Київ : НАВС, 1996.

12. Белкин Р.С. Курс криминалистики. В 3 т. Т. 2, Частные криминалистические теории. Москва : Юристъ, 1997. 
13. Белкин Р.С Криминалистическая энциклопедия. Москва : БЕК, 1997. С. 172.

14. Бердичевский Ф.Ю. О предмете и понятийном аппарате криминалистики. Вопросы борьбы с преступностью. Москва, 1976. Вып. 24.

15. Бордюгов Л. Г. Профілактична функція судової екологічної експертизи. URL : http://nauka.kushnir.mk.ua

16. Бычкова С.Ф. Становление и тенденции развития науки о судебной экспертизе. Алма-Ата, 1992.

17. Винберг А.И., Малаховская Н.Т. Судебная экспертология. Общетеоретические и методологические проблемы судебных экспертиз : Учеб. пособ. Волгоград : НИиРИО ВШ МВД СССР, 1979.

18. Демичев В.А. Объект и предмет науки. Научные доклады высшей иколь: Философские науки. 1983. 5.

19. Долгова А.И. Криминология. Москва : Издательская группа НОРМАИНФРА, 1999.

20. Зудин В.Ф. Предупреждение преступлений в практике судебной экспертизы. Советская юстиция, 1962. 21.

21. Калдин В.Я. Теоретические основы и практика применения идентификации при расследовании и судебном рассмотрении уголовных дел : автореф. дис. ... д-ра юрид. наук. 1970.

22. Клименко Н.І. Судова експертологія: Курс лекцій : навчальний посіб. для студ. Київ : Видавничий Дім «Ін Юре», 2007.

23. Козлов В.А. Проблемы предмета и методологии общей теории права. Ленинград, 1989.

24. Колмаков В.П. Некоторые вопросы криминалистической профилактики преступлений. Советское государство и право, 1961. 12.

25. Конспект лекцій 3 дисципліни «Експертологія» для студентів юридичного факультету. ДДУВС. Дніпро, 2016. URL : https://dduvs.in.ua/ wp-content/uploads/files/Structure/library/student/lectures/1130/3.1.pdf.

26. Криминология. Учебник для юридических вузов / Под общей редакцией доктора юридических наук, профессора А.И. Долговой. Москва : Издательская группа НОРМА ИНФРА, 1999.

27. Криміналістика і судова експертиза: міжвідом. наук.-метод. зб., присвяч. 105-річчю заснування судової експертизи в Україні / Київський НДІ судових експертиз; редкол.: О. Г. Рувін та ін. Київ : Видавництво Ліра-К, 2018. Вип. 63. 1.

28. Ковальова В.В. Шляхи удосконалення експертно-криміналістичної служби МВС України : автореф. дисс. ... канд. юрид. наук. 2001. 
29. Машков А. Проблеми теорії держави і права. Основи: Курс лекцій. URL : https://pidruchniki.com/12461220/pravo/viznachennya_ponyat_obyekt_ nauki_predmet_nauki_zagalna_harakteristika_protsesu_formuvannya.

30. Основи судової експертизи: навчальний посібник для фахівців, які мають намір отримати або підтвердити кваліфікацію судового експерта / авт.-уклад.: Л.М. Головченко, А.І. Лозовий, Е.Б. Сімакова-Сфремян та ін. Харків : Право, 2016. 928.

31. Пиріг І.В. Теоретичні основи експертного забезпечення досудового розслідування : дис. ... д-ра юрид. наук: 12. 00. 09. Харків, 2015.

32. Потапов С.М. Введение в криминалистику. Москва : Госюриздат, 1946. $285 \mathrm{c}$.

33. Русецький А.А., Угровецький О.П. Місце експертної профілактики в системі протидії злочинності. Актуальні питання судової експертизи та криміналістики : зб. матеріалів міжнар. наук. -практ. конф., присвяч. 95річчю створення. Харків : НДІ суд. експертиз ім. Засл. проф. М.С. Бокаріуса (Харків, 10-11 жовт. 2018 р.). Харків : Право, 2018.

34. Сегай М.Я. Судова експертологія: шляхи становлення та розвитку. Теорія та практика судової експертизи і криміналістики: 3б. наук. практ. матеріалів / За загал. ред. М.Л. Цимбал, Е.Б. Сімакова-Сфремян, В.М. Шерстюк та ін. Харків : Право, 2001.

35. Тевлін Р. Про поняття «правоохоронні органи» у вузькому та широкому розумінні. Право. 985. Вип. 7.

36. Філіпенко Н.С. Приватна теорія експертної превенції: генеза та сучасний стан. Науковий вісник ДДУВС: науковий журнал. 2019. № 3.

37. Філіпенко Н.С., Угровецький О.П., Шарапова О.В. Теоретичні основи експертної профілактики: поняття та завдання. Теорія та практика судової експертизи і криміналістики. Том 20. № 2(2019), 2019.

38. Filipenko N.Ye. Identification of crime determinants while performing forensic expert activities. Proceedings of VI International scientific conference "Scientific achievements during the rapid technological development". Berlin, tredition GmbH, 2019. P. 161- 167.

39. Фридман И.Я. Судебная экспертиза и вопросы предупреждения преступлений : автореф. дис...д-ра юрид. наук, 1974.

40. Фридман И.Я. Вопросы правового регулирования профилактической деятельности экспертов и судебно-экспертных учреждений. Криминалистика и судебная экспертиза. Вып. 6. Киев, 1976.

41. Шепитько В.Ю. О новеллах в использовании специальных знаний в уголовном процессе Украины. Теория и практика судебной экспертизы в современных условиях : материалы 4-й междунар. науч.-практ. конф. (г. Москва, 30-31 янв. 2013. Москва : Проспект, 2013. 
42. Эйсман А.А. Экспертология в системе научного знания. Эксnертные задачи и пути их решения в свете НТР: Сб. науч. тр. ВНИИСЭ. Москва : ВНИИСЭ, 1980.

43. Експертизи в судовій практиці / За заг. ред. В.Г. Гончаренка. Київ : Юрінком Інтер, 2005.

\section{Information about authors:} Filipenko N. Ye.,

$\mathrm{PhD}$ in Law, Associate Professor, Associate Professor at the Law Department National Aerospace University "Kharkiv Aviation Institute"

17, Chkalova str., Kharkiv, 61070, Ukraine

Spitsyna H. O., Doctor of Law, Associate Professor, Professor at the Law Department National Aerospace University "Kharkiv Aviation Institute" 17, Chkalova str., Kharkiv, 61070, Ukraine 